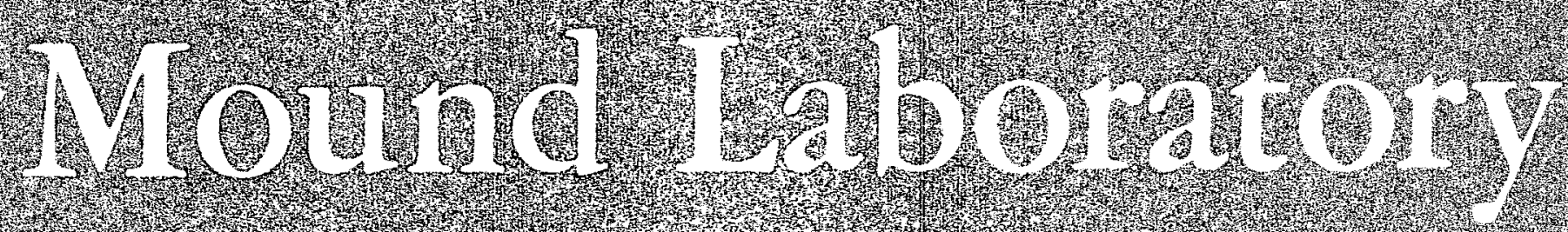

\title{
MIAMISBURG, OHIO
}

operated by

Monsanto

Chenical Company

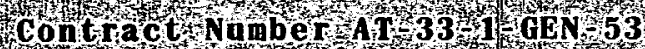

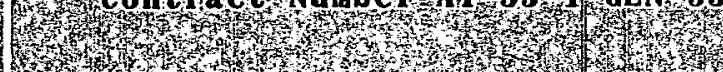

THERMAU BAT TERTES USING POLONIUM 210

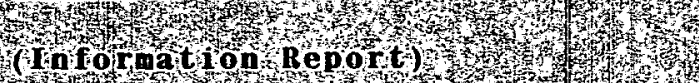




\section{DISCLAIMER}

This report was prepared as an account of work sponsored by an agency of the United States Government. Neither the United States Government nor any agency Thereof, nor any of their employees, makes any warranty, express or implied, or assumes any legal liability or responsibility for the accuracy, completeness, or usefulness of any information, apparatus, product, or process disclosed, or represents that its use would not infringe privately owned rights. Reference herein to any specific commercial product, process, or service by trade name, trademark, manufacturer, or otherwise does not necessarily constitute or imply its endorsement, recommendation, or favoring by the United States Government or any agency thereof. The views and opinions of authors expressed herein do not necessarily state or reflect those of the United States Government or any agency thereof. 


\section{DISCLAIMER}

Portions of this document may be illegible in electronic image products. Images are produced from the best available original document. 
W.0. 共 46073

MLM-984

Category - PHYSICS

$-1-$

MLM -984

THERMAL BATTERIES USING POLONIUM- 210

(Information Report)

BY

K. C. JORDAN ANंD J。H, BIRDEN

Date: June: 2,1954

This document is

PUBLICLY RELEASABLE

Bam steab

Authorizing Offlcial

Date: $\quad 7-30.07$ 
Category - PHYSICS

\section{STANDARD : DISTRIBUTION}

Mound Laboratory

Argonne Cancer Research Hospital

Argonne' National Laboratory

Armed Forces Special Feapons Project, Vashington

Armed Services Technical Information Agency, Dayton

Army Chemical Center

Army Medical Research Laboratory

Army Medical Service Graduate School

Atomic Bomb Casualty Commission. (APO-182)

Atomic Energy Commission, Patent Branch

A tomic Energy Commission, Technical Library

Atomic Energy. of Canada Limited

Australian Atomic Energy Comission

Battelle Memorial. Institute

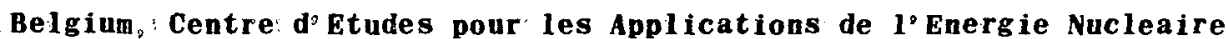

Belgium; Union Miniere du Haut Katanga

Boeing. Airplane Company

Brookhaven: National: Laboratory

Brush : Beryllium Company

Bureau of Ships (Code 490 )

Carbide and Carbon Chemicals Company, C-31 Plant

Carbide: and Carbon Chemicals, Company, K-25 Plant

Carbide and Carbon Chemicals Company, ORNL

Carnegie Institute of Technology

Chalk River Project, Canada

Chicago Patent Group

Columbia: University (Dr, Failla)

Columbia University (Dr。Hassialis)

Columbia University: (Dr。 Havens)

Consolidated Vultee Aircraft Corporation

Department of Army office of ordnance Research

Department of: Navy。 Code 811

Division of Raw Materials, Denver

Division of Baw Haterials, Ishpeming

Dow Chemical Company, Midland

Dow Chemical Company : Rocky Flats

duPont Company, Savannah River Plant

duPont Company, Wilmingt on

Frankford Arsenal

GE A tomic Products Division.

General: Electric Company (ANPP)

Generali Electric Company, Richland

Goodyear: Atomic Corporation

Grand Junction Operations office, Exploration: Division

Harshaw: Chemical: Corporation

Iowa: State: College

Italy, :entro: Italian Studi : Experienze

Johns Hopkins: Uni versity

Kaiser' Engineers

Kirtland Air Force Base

Knolls: Atomic Power Laboratory

Lockheed Aircraft Corporation

Los: Alamos: Scientific Laboratory

Number of Copies

44

1

6

2

1

1

1

1 
Category - PHYSICS

\title{
STANDARD DISTRIBUTION (CONT"D)
}

\author{
Mallinckrodt Chemical Works \\ Massachusetts Institute of Technology (Dr. Hardy) \\ Massachusetts Institute of Technology (Dr; Ranfuann) \\ Nationa 1 Advisory Committee for: Aeronautics, Cleveland \\ National Bureau of Standards; Atomic Energy Project \\ Nationa 1 Bureau of Standards, : Library \\ National Lead Company of ohio \\ National Research Corporation \\ National Research Council, Canada \\ Naval Medical Research Institute \\ Naval Besearch Laboratory \\ New Brunswick Laboratory \\ Newport News Shipbuilding: and Dry Dock Company \\ New York Operations office \\ New York University (Dr。E。Bromberg) \\ North American Aviation, Inc. \\ Nuclear Development Associates, Inc. \\ oak Ridge Institute of Nuclear studies \\ Phillips Petroleum Company \\ Princeton University \\ Public' Health Service \\ RAND Corporation \\ Sandia corporation \\ Technical Information Service, oak Ridge \\ Tokyo University \\ United Aircraft Corporation \\ United Kingdom Scientific Mission \\ $U_{\text {。 }}$ 。 Geological Survey (ur. Butler) \\ $U_{\text {: }} S_{\circ}$ Geological Survey, Denver (Librarian) \\ $\mathbf{U}_{\circ} \mathbf{S}_{o}$ Geological Survey; Washington (Librarian) \\ $U_{\mathrm{o}} S$. Naval Radiological Defenser Laboratory \\ UCLA Medical Research Laboratory \\ University of California Radiation Laboratory \\ University of California Badiation Laboratory, Livermore site \\ University of Michigan (Dr. Gomberg) \\ University of Rochester (Dr. Marshak) \\ University of Bochester, Atomic Energy' Project \\ University of Utah \\ University of Hashington (Dr. Manley) \\ Vitro Corporation of America \\ Valter: Kidde: Nuclear: Laboratories, Inc. \\ Watertown Arsenal \\ Teil。' Dr, George: $L$. \\ Western Reserve University \\ Westinghouse: Electric Corporation \\ Yale University (Gregory Breit) \\ Yale University (Dr. Wadey)
}




\title{
STANDARD DISTRIBUTION
}

\author{
1. Carroll A. Hochwalt \\ 2. N. N. T. Samaras \\ 3. J. J. Burbage \\ 4. E. C. McCarthy \\ 5. J. F. Eichelberger \\ 6. D. L. $S \cot t$ \\ 7. J. W. Heyd \\ 8. R. K. Davis \\ 9. R. A. Miller \\ 10. D. L. Timma \\ 11. R. G。 $01 t$ \\ 12. J。 R. Parks \\ 13. K. C. Jordan \\ 14. J. H. Birden \\ 15. J. W. Wright \\ 16. E. G. Linder, Radio Corporation of America \\ 17. S, W. Scott, Patent Branch, Oak Ridge \\ 18. K. Kasschau, Office Res, and Med。, Oak Ridge \\ 19. F. R. Dowling, office Eng, and Prod, oak Ridge \\ 20. J. H. Roberson, Area Manager, AEC, Dayton, Ohio \\ 21 44. Central Files
}

Issued:

OCT $6 \quad 1954$ 


\begin{abstract}
The general theory of thermal batteries of the thermopile type is developed and this theory is applied to the design of batteries powered by $\mathrm{Po}^{210}$ heat sources. The physical characteristics, performance, and fabrication of two experimental. batteries with 57 and 146 curies, respectively, of $\mathrm{Po}^{210}$ are described. Maximum electrical power delivered to a load was 0.1 and 0.2 per cent of the power developed as heat by the polonium. The work capacity of the thermal batteries is 1.8 and 9.2 times, respectively, that of a commercial mercury battery (RM4Z) and the weight is 30 per cent less.
\end{abstract}

\title{
IN TRODUCTION
}

Thermal batteries using a thermopile (more than one thermocouple) to convert heat to electricity were investigated many years ago and abandoned as economical means of generating commercial amounts of electrical power. However, such batteries are used extensively in many special applications.

When powered by radioactive substances these batteries become even less economical, but they may have special applications as a result of the high specific amounts of energy released by all radioactive materials. The rate at which this energy is released and consequently the life of the battery, is determined by the half-life of the radioactive material which can not be changed by physical conditions.

To illustrate the amount of power developed by radioactive substances the theoretical temperature which is attained by a solid sphere of polonium-210 in a vacuum can be calculated. The density of polonium-210 is about 9 grams per cubic centimeter, the specific activity is $2.2 \times 10^{-4}$ grams per curie, and the power generated is .032 watt per curie. A solid sphere 0.1 inch in diameter could contain 350 curies of polonium-210 which will generate 11.3 watts of heat. If such a sphere were suspended in an evacuated chamber its surface (assuming an emissivity of 0.25 ) would reach a temperature of $2,200^{\circ} \mathrm{C}$. Polonium must be hermetically sealed in very strong and dense capsules, consequently the surface temperature of the capsules will be much cooler than the temperatures calculated above.

Thermal batteries consist of a quantity of polonium or other radioactive material contained in a capsule which is thermally.insulated from and positioned within a secondary container of about three times the dimensions of the capsule. The hot junctions of thermocouples with high thermoelectric power are thermally, but not electrically, connected to the capsule; and the cold junctions are connected in the same way to the outer container. The thermocouples are electrically connected in series on the surface of the outer container. After a time the temperatures of the system reach: a steady state with a difference of temperature existing between hot and cold junctions, which temperature difference causes a voltage proportional to the temperature difference to be generated in the thermocouples.

\section{NOMENCL ATURE}

$a, a_{1}, a_{2}-$ radius of wire and of each type of wire, $\mathrm{cm}$

$\beta$ - thermoelectric power of each thermocouple, volts $/{ }^{\circ} \mathrm{C}$

$e$ - voltage generated per couple, volts 
$f-$ ratio of $R_{t}$ to $\left(R_{s}+R_{c}\right)$

$H$ - surface radiation from wires, cal $/(\mathrm{sec})\left({ }^{\circ} \mathrm{C}\right)(\mathrm{sq} \mathrm{cm})$

$\rho_{t} . \rho_{t, 1}, \rho_{t, 2}$ - thermal resistivity (inverse of conductivity) of wire and of each type of wire, $\left({ }^{\circ} \mathrm{C}\right)(\mathrm{sq} \mathrm{cm}) /(\mathrm{cal} / \mathrm{sec})(\mathrm{cm})$

$l$ - length of each lead (distance between hot and cold junctions), cm

$m$ - ratio of $R_{C}$ to $R_{S}$

$n$ - number of hot (or cold) junctions

$q$ - lateral loss of heat per lead, cal/sec

$\rho_{e}, \rho_{e, 1}, \rho_{e, 2}-$ electrical resistivity of wire and of each type of wire, (ohms) $(\mathrm{sq} \mathrm{cm}) / \mathrm{cm}$

$R_{C}$ - thermal resistance from capsule to hot junctions, $\left({ }^{\circ} \mathrm{C}\right)(\mathrm{sec}) / \mathrm{cal}$

$R_{t}$ - thermal resistance of all the leads from hot to cold junctions, $\left({ }^{\circ} \mathrm{C}\right)(\mathrm{sec}) / \mathrm{cal}$

$R_{S}$ - thermal resistance of the space between capsule and outer container。 $\left({ }^{\circ} \mathrm{C}\right)(\mathrm{sec}) / \mathrm{cal}$

$r$ - series resistance of both leads forming a junction, ohms

$r_{1}, r_{2}$ - resistance per lead of each type of wire, ohms

$T$ - absolute temperature, ${ }^{\circ} \mathrm{K}$

$T_{1}, T_{2}$ - temperature of hot and cold junctions, ${ }^{\circ} \mathrm{K}$

$\Delta T-\left(T_{1}-T_{2}\right),{ }^{\circ} \mathrm{C}$

$W_{L}$ - power dissipated in load, watts

$W_{S}$ - heat generated by radioactivity within the capsule, watts

\section{THEORY OF THE THERMAL BATTERY}

Equations for the efficiency of the thermal battery can be developed and the final equation (Eq 17) will be one in terms of the absolute temperatures of the hot and cold junctions.

Figure 1 is a diagram of the electrical circuit of a thermal battery and Figure 2 is an equivalent: circuit diagram of the thermal circuit.

Maximum power will be developed with a load resistance equal to the internal resistance of the battery, Figure 1:

$$
W_{L}=\frac{(n e)^{2}}{4 n r}=\frac{n e^{2}}{4 r} \quad \text { watts }
$$

The efficiency is:

$$
\text { Eff }=\frac{100 W_{L}}{W_{S}}=\frac{25 n e^{2}}{W_{S} r} \quad \text { per cent }
$$




$$
7 \text { figl }
$$

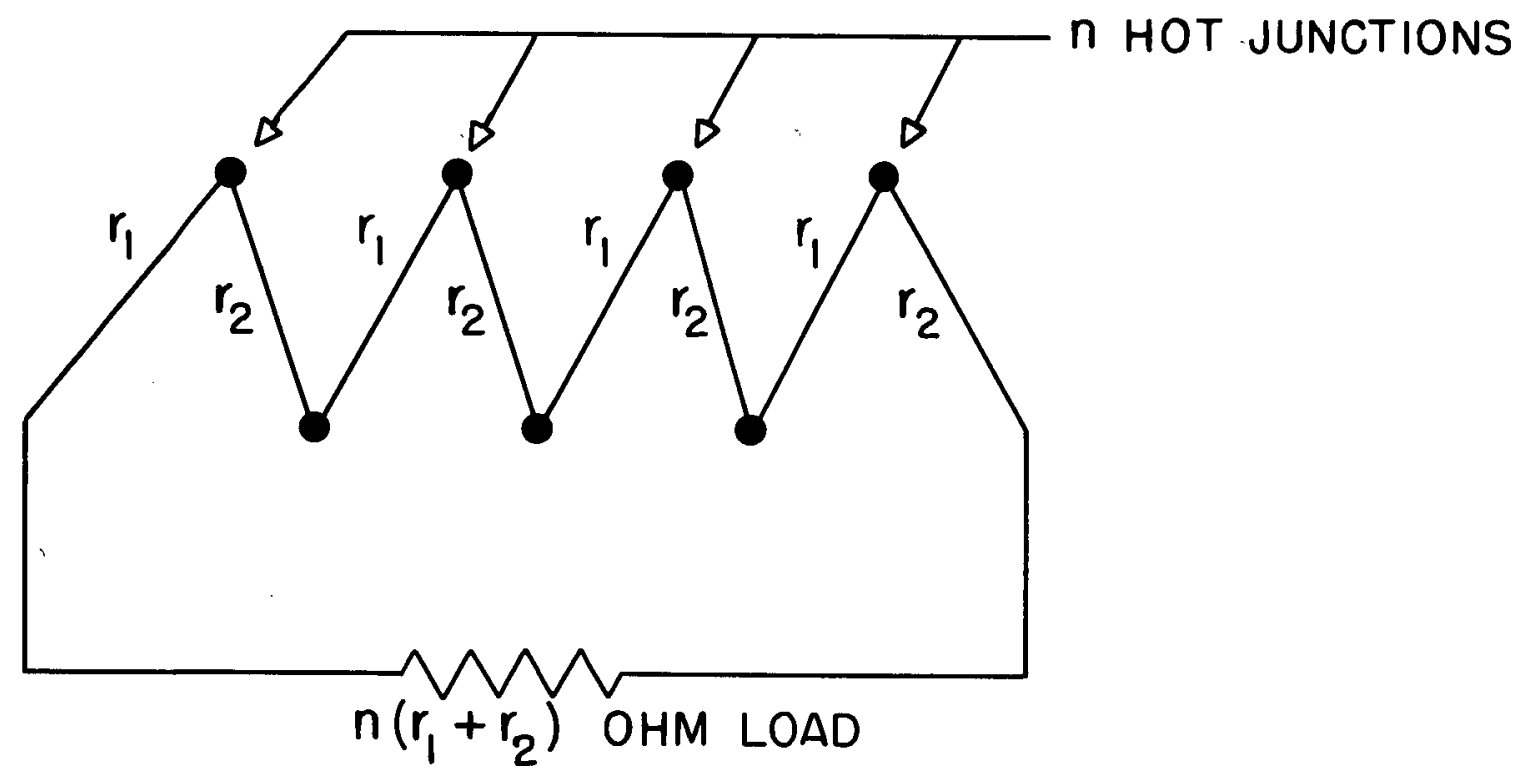

ELECTRICAL CIRCUIT 


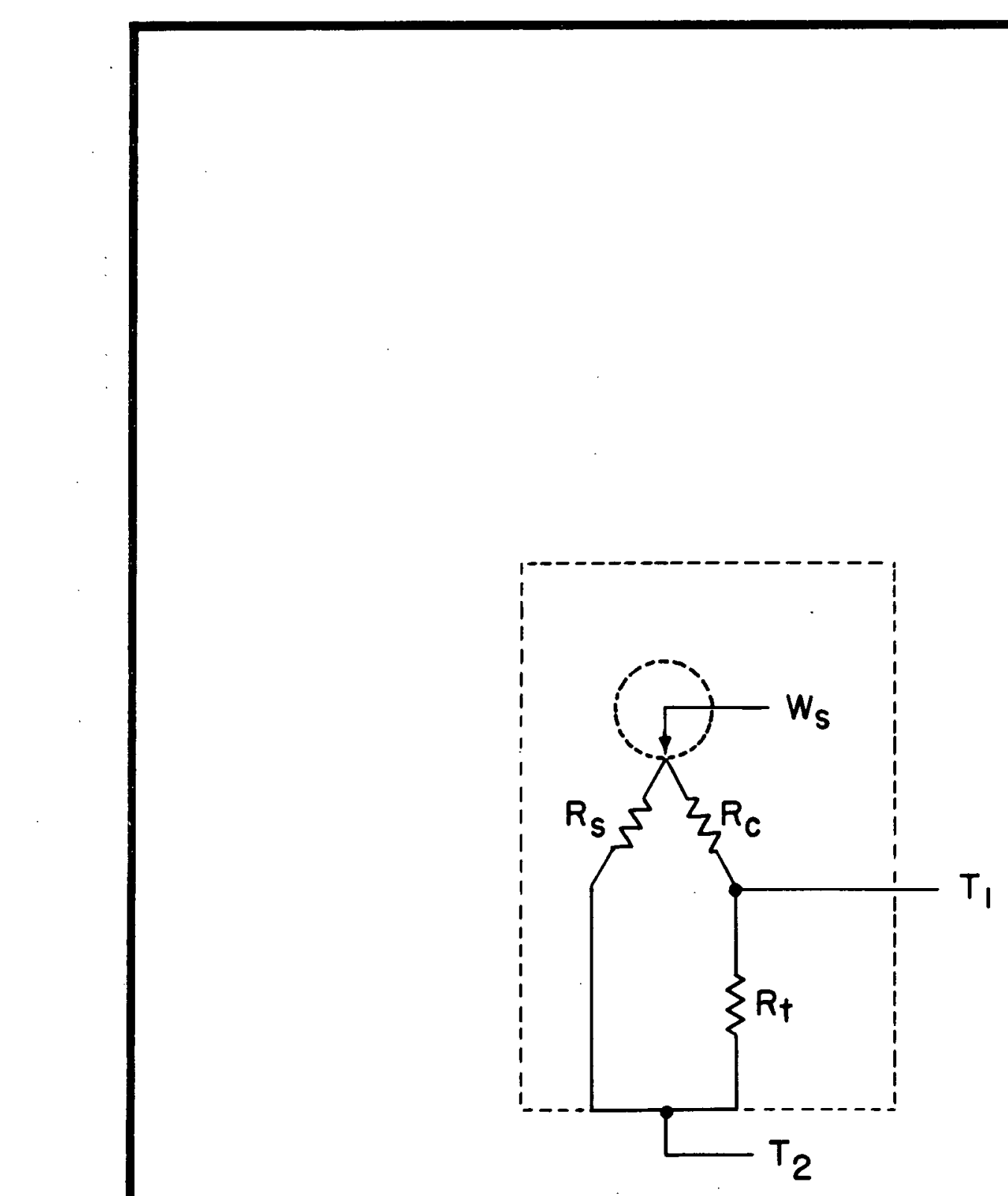

\section{THERMAL CIRCUIT}

$m$
in

\section{FI GURE 2}


The voltage generated by each thermocouple is:

$$
e=\beta\left(T_{1}-T_{2}\right)=\beta \Delta T \quad \text { volts }
$$

In the steady'state the thermal circuit, Figure 2, can be represented by $R_{S}$ in parallel with $R_{c}$ and $R_{t}$ connected in series. All of the heat from the source less that converted to electrical power $\left(W_{S}-2 W_{L}\right)$ flows through the parallel network. The temperature difference $\triangle T$ is measured across $R_{t}$ and is:

$$
\Delta T=\frac{R_{t} R_{S}\left(W_{S}-2 W_{L}\right)}{4.185\left(R_{t}+R_{S}+R_{C}\right)} \quad{ }^{\circ} \mathrm{C}
$$

- Since $W_{L}$ is small in comparison to $W_{S}$, Equation (4) can be adequately represented by:

$$
\Delta T=\frac{R_{t} R_{s} W_{s}}{4.185\left(R_{t}+R_{s}+R_{C}\right)} \quad{ }^{\circ} \mathrm{C}
$$

Substituting Equations (3) and (5) in Equation (2):

$$
\text { Eff }=\frac{25 n \cdot \beta^{2} R_{t}{ }^{2} R_{s}^{2} W_{s}}{(4.185)^{2}\left(R_{t}+R_{s}+R_{C}\right)^{2} r} \quad \text { per cent }
$$

Electrical and thermal resistivities are related by the Wiedemann-Franz law:

$$
\frac{\rho_{e}}{\rho_{t} T}=\text { a constant }=a \quad(\mathrm{cal} / \mathrm{sec}) /\left({ }^{\circ} \mathrm{C}\right)(\mathrm{ohms})\left({ }^{\circ} \mathrm{C}\right)
$$

The constant $\alpha$ has a value of about $5: 5 \times 10^{-8}$ for all pure metals and is usually higher for alloys, especially for alloys of higher electrical resistivity. It has a value of about $8 \times 10^{-8}$ for constantan and about $10^{\circ} \times 10^{-\theta}$ for chromel. (As will be evident below the increase in efficiency resulting from the greater thermal power of chrome $1-$ constantan over iron-constantan is partially cancelled by the greater Wiedemann-Franz constant of chromel.) The electrical resistance per lead of each type of wire is:

$$
r_{1}=\frac{\rho_{e, 1} l}{\pi a_{1}^{2}} ; r_{2}=\frac{\rho_{e, 2} l}{\pi a_{2}^{2}} \quad \text { ohms }
$$

The diameter of each type of wire should be chosen such that the thermal resistance of each lead is the same

$$
r_{t}=\frac{\rho t, 1}{\pi a_{1}^{2}}=\frac{\rho t, 2 l}{\pi a_{2}^{2}}
$$


Dividing Equations (7) and (8) by Equation: (9) and making use of Equation (7) gives:

$$
\begin{aligned}
& r_{1}=r_{t} a_{1}\left(\frac{T_{1}+T_{2}}{2}\right) \\
& r_{2}=r_{t} a_{2}\left(\frac{T_{1}+T_{2}}{2}\right)
\end{aligned}
$$

Adding both parts of Equation (10) gives:

$$
r=r_{1}+r_{2}=r_{t}\left(a_{1}+a_{2}\right)\left(\frac{T_{1}+T_{2}}{2}\right)
$$

Since all of the leads are in parallel thermally,

$$
r_{t}=2 n R_{t}
$$

which, substituted in Equation (11), gives:

$$
r=n R_{t}\left(a_{1}+a_{2}\right)\left(T_{1}+T_{2}\right)
$$

Solving Equation (12) for $R_{t}$ and substituting for one $R_{t}$ in the numerator of Equation (6) gives:

$$
\operatorname{Eff}=\frac{1.43 \cdot \beta^{2} R_{s}^{2} R_{t}}{\left(a_{1}+a_{2}\right)\left(R_{t}+R_{s}+R_{c}\right)^{2}\left(T_{1}+T_{2}\right)}
$$

The relative magnitude of the thermal resistance terms can be expressed by:

$$
\begin{aligned}
& R_{c}=m R_{s} \\
& R_{t}=f\left(R_{s}+R_{c}\right)=f R_{s}(1+m)
\end{aligned}
$$

Substituting Equations (14) and (15) in Equation (13) gives:

$$
\operatorname{Eff}=\frac{1.43 \cdot \beta^{2} \cdot R_{s} W_{s}}{\left(a_{1}+a_{2}\right)(1+m)\left(T_{1}+T_{2}\right)} \cdot \frac{f}{(f+1)^{2}} \quad \text { per cent }
$$

The term $f /(f+1)^{2}$ has a maximum of .25 for $f=1$, which means that for maximum efficiency the leads: should have a thermal resistance equal to $R_{s}+R_{c^{\circ}}$ If this condition is always sat isfied:

$$
T_{1}-T_{2}=\Delta T=\frac{W_{S} R_{S}}{2 \times 4.185}
$$


Substituting Equation (17) in Equation (16) and letting

$$
f /(f+1)^{2}=.25
$$

gives the maximum efficiency:

$$
\operatorname{Eff}_{(\max )}=\frac{3.0 \cdot \beta^{2}}{\left(a_{1}+a_{2}\right)(1+m)} \frac{T_{1}-T_{2}}{T_{1}+T_{2}} \quad \text { per cent }
$$

Several general statements can now be made concerning the design of thermal batteries and similar devices:

1. When the hot junctions are in good thermal contact with the source of heat $(m \rightarrow 0)$, the maximum efficiency is obtained when one-half of the heat flows through the leads.

2. Like all heat engines, the efficiency of a thermal battery is dependent upon absolute tempe ratures (Eq 18).

3. The efficiency is independent of the number of junctions. However, from practical considerations, the thermal resistance between capsule and hot junctions tends to increase slightly with the number of junctions which increases the term $(1+m)_{0}$ and so decreases the efficiency. Metallic contact between capsule and junction is possible for a single junction $(m \rightarrow 0)$.

4. The internal resistance of the battery increases as the square of the number of junctions (Eq 12).

5. The voltage of the battery is proportional to the number of junctions.

Another factor which tends to lower the efficiency and has not been included in the derivation of Equations (16) and (18)' is the lateral loss of heat by radiation along the wires. This loss of heat has the same effect as an increase in the Wiedemann-Franz constant As a first approximation the loss of heat per lead is:

$$
q=\pi \operatorname{aH} l\left(T_{1}-T_{2}\right) \quad \mathrm{cal} / \mathrm{sec}
$$

Where

$q$ - is the lateral loss of heat along each lead, calł sec

$a-$ is the radius of each 1 ead, $\mathrm{cm}$

$H$ - is the surface radiation, cal $/(\mathrm{sec})\left({ }^{\circ} \mathrm{C}\right)(\mathrm{sq} \mathrm{cm})$

$l=$ is the length of the leads, cm

The total lateral loss of heat can be included by assuming a thermal resistance of $1 / n \pi a H l$ in parallel with all of the leads of each type of wire, and therefore the adjusted WiedemanntFranz constant for each type of wire is:

$$
\alpha_{(\operatorname{adj})}=\alpha\left(1+\pi n \text { a } H l R_{t}\right)(\mathrm{cal} / \mathrm{sec}) /\left({ }^{\circ} \mathrm{C}\right)(\mathrm{ohms})\left({ }^{\circ} \mathrm{C}\right)
$$


When the capsule size, the insulating material, dimensions of outer container, and type of wire have been determined, all of the variables in Equation (20) are fixed except $n$ and $a$. Since $a$ is inversely proportional to the square root of $n$ : Equation (19) can be written:

$$
\alpha_{(\operatorname{adj})}=\alpha(1+K \sqrt{n})
$$

This is another reason for a decrease in efficiency with an increase in the number of $j$ unctions. With a fixed number of junctions the radius of the wire changes with the WiedemannFranz constant and with the resistivity. The relative radii of the two wires can be determined by substituting Equation (8) in Equation (10):

$$
\frac{a_{1}}{a_{2}}=\sqrt{\frac{a_{2} \rho_{e, 1}}{a_{1} \rho_{e, 2}}}
$$

Still another loss of efficiency might occur if the cold junctions were somewhat hotter than the outside container. This can be minimized, without introducing other losses in efficiency, by using cold junctions having a large surface area.

If $R_{S}$ were very large, a condition which could be realized by placing the radioactivity within the junctions, the efficiency with the same working temperatures would be twice as great and $m=0$ :

$$
\text { Wff }=\frac{6.0 \cdot \beta^{2}\left(T_{1}-T_{2}\right)}{\left(a_{1}+a_{2}\right)\left(T_{1}+T_{2}\right)} \quad \text { per cent }
$$

Also the adjusted Wiedemann-Franz constant as given by Equation (20) would apply to Equation (23) and give a more exact statement of the efficiency. Such a junction must be fabricated in order to determine the effect of the activity upon the thermoelectric power and also upon the life of the junction.

The maximum theoretical efficiency may be readily calculated from Equation (23). Thus for $T_{1} \gg T_{2}$, the maximum theoretical efficiency is:

$$
\text { Eff }=\frac{6 \cdot \beta^{2}}{a_{1}+a_{2}} \quad \text { per cent }
$$

For bismuth-antimony couples

$$
\begin{aligned}
& \beta=12 \times 10^{-5} \\
& a_{1}=7.7 \times 10^{-8} \\
& a_{2}=5.8 \times 10^{-8}
\end{aligned}
$$

the maximum theoretical efficiency would be 6.4 per cent. An efficiency of this magnitude probably will never be obtained. 


\section{DESIGN OF THERMAL BAT TERIES}

In the design of a thermal battery perhaps the first factor to be determined is the type of thermocouple which will be used. Because the efficiency is proportional to the square of the thermoelectric power, this will be the most important factor. However, other factors must be considered, such as melting points, welding or soldering properties. Wiedemann-Franz constant, and resistivity. of the commercial varieties of thermocouple materials, chromel. constantan and iron-constantan have the largest thermoelectric power and are satisfactory in all other respects. Bismuth-antimony couples have an appreciably higher thermoelectric power, but are difficult to fabricate and their melting points are low. Other thermocouples have been developed recently with reportedly higher thermoelectric power but no definite information concerning them is available.

The relative merits of chromel-constantan and iron-constantan couples may be compared. The thermoelectric power of these couples increases with temperature and at $300^{\circ} \mathrm{C}$ chromelconstantan has a value of $\beta=7.7 \times 10^{-5}$ volts per degree $C$ and iron-constantan has a value of $\beta=5.5 \times 10^{-5}$ volts per degree $C$. The Wiedemann-Franz constants are $5.5 \times 10^{-9}, 8 \times 10^{-9}$, and $10 \times 10^{-9}$ (cal/sec) $/\left({ }^{\circ} \mathrm{C}\right)(\mathrm{ohm})\left({ }^{\circ} \mathrm{C}\right)$. respectively for iron, constantan, and chromel. From Equation (16) or (18) the efficiency of chromel-constantan relative to iron-constantan is:

$$
\left(\frac{7.7}{5.5}\right)^{2}\left(\frac{5.5+8}{8+10}\right)=1.5
$$

The electrical resistivities are $10 \times 10^{-8}, 44 \times 10^{-8}$, and $65 \times 10^{-6}$ (ohm) (cm) respectively。 for iron, constantan, and chromel. The radius of a chromel wire relative to an iron wire is, from Equation (22);

$$
\sqrt{\frac{5.5 \times 65}{10 \times 10}}=1.9
$$

The larger chromel wire will increase the adjusted Wiedemann-Franz constant given by Equation (20) by an amount depending on the number of junctions. This will further reduce the relative efficiency of the two types of thermocouples. However in most cases the efficiency of the chromel-constantan junctions will be higher than the corresponding iron-constantan couples.

\section{CHARACTERISTICS OF EXPERIMENTAL BATTERIES}

Two experimental batteries were constructed to check the validity of the theory and to develop techniques of fabrication. Physical and performance characteristics of these two batteries are listed in Table I. Details of construction of the two batteries are shown in Figures 3 and 4 .

\section{HEAT SOURCE}

A heat source was required having dimensions of approximately 0.2 inch in diameter and 0.4 inch in length. Such a heat source was prepared by volatilizing polonium-210 into a capsule or container, closing the capsule with a plug, and coating the capsule with nickel. The finished heat source measured 0.21 inch in diameter by 0.45 inch in length 


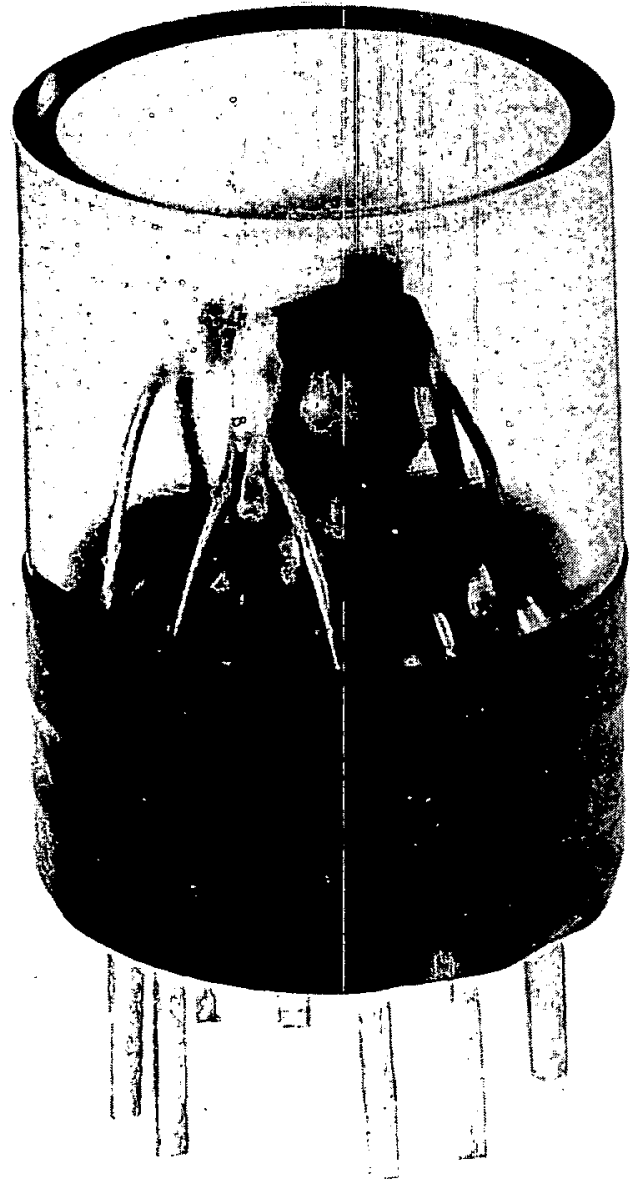

10
0
0
0
0

BATTERY NUMBER I

F I GURE 3 

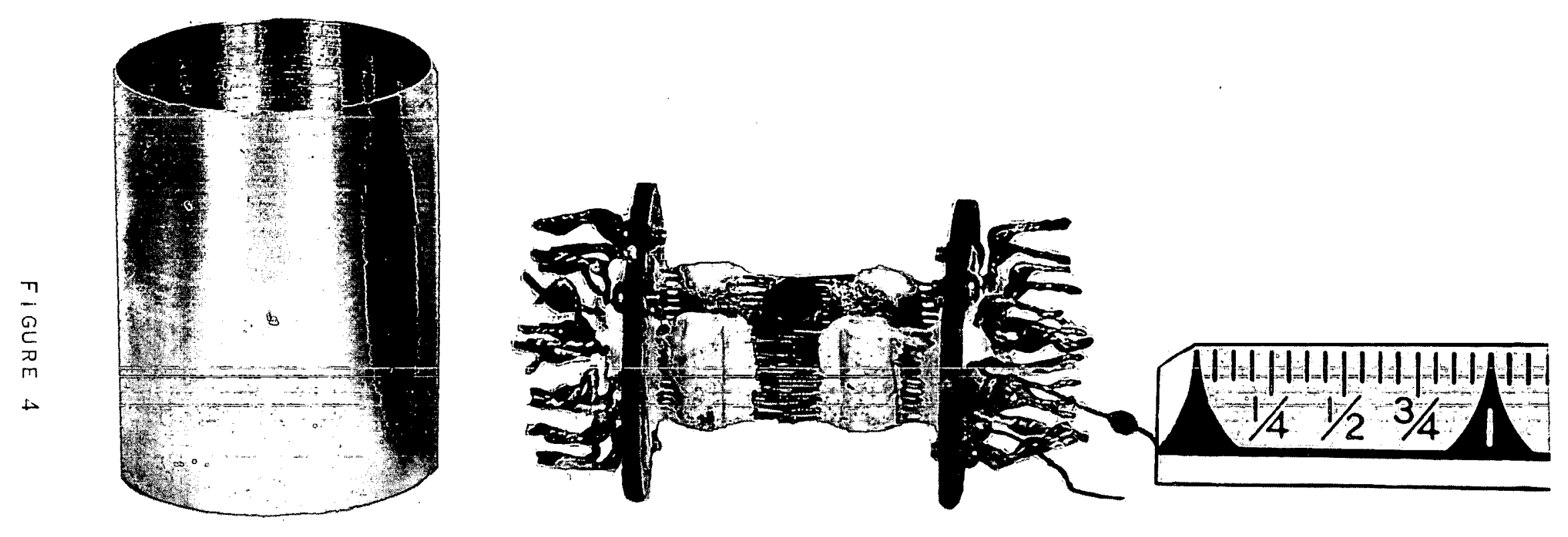


\section{TABLE :}

\section{CHARACTERISTIICS OF EXPERIMENTAL BATTERIES}

BATTERY NO. 1

RADIOACTIVITY

CAPSULE CONTAINING Po 210 :

MATERIAL OF CAPSULE

THERMOCOUPLES

NUMBER OF JUNCTIONS

LENGTH OF LEADS

WIRE SIZES

INSULATION BETWEEN

JUNCTIONS AND CAPSULE

ESTIMATED $m$

INSULATING MATERIAL

OUTSIDE CONTAINER

INTERNAL RESISTANCE

VOLTAGE AT NO LOAD

TEMPERATURE RISE FROM HOT

TO COLD JUNCTIONS $\left(T_{1}-T_{2}\right)$

TEMPERATURE OF COLD

JUNCTION $\left(T_{2}\right)$

TEMPERATURE OF CAPSULE

(BASED ON $m$ ABOVE)

MAX POWER DELIVERED

ACTIVITY OF PO210: IN WATTS

EFFICIENCY

WE IGHT

WORK CAPACITY

CURRENT AT MAX POWER
57 CURIES. Po 210

SPHERE . O.D. 0.4 IN

COLD.ROLLED STEEL W!TH

0.02 IN. NICKEL COATING

SILVER: SOLDERED CHROMEL. CONSTANTAN

7

$1.2 \mathrm{~cm}$

B AND $S$ NO. 18 CHROMEL

B AND $S$ NO. 20 CONSTANTAN

SAUERE ISEN CEMENT

0.3

SANTOCEL

LUCITE CYLINDER

$$
0.25 \mathrm{oHM}
$$

42 MiLLIVOLTS

$42 / 7 \times 7.7 \times 10^{-2}=78^{\circ} \mathrm{C}$

$45^{\circ} \mathrm{C}$

$146^{\circ} \mathrm{C}$

1.8 MILLIWATTS

1.8 WATTS

0.10 PER CENT

34 GMS

$1.5 \times 10^{4}$ JOULES

85 MILL! AMPS
BATTERY NO. 2

146 CUR!ES, Po 210

CYL.INDER，O.D：0.21 iN. LENGTH $0.45: \mathrm{N}$.

COLD-ROLLED STEEL WITH

0.02 IN. OF NICKEL COATING

WELDED CHROMEL - CONSTANTAN

40

$1.3 \mathrm{CM}$

B AND 5 NO. 29 CHROMEL

B AND $S$ NO. 30 CONSTANTAN

SAUERE ISEN CEMENT

0.2

SANTOCEL

ALUMINUM CYLINDER

15 OHMS

750 MIL.LIVOL.TS

$750 / 40 \times 7.7 \times 1 \sigma^{2}=244^{\circ} \mathrm{C}$

$80^{\circ} \mathrm{C}$

$373^{\circ} \mathrm{C}$

9.4 MILL. IWATTS

4.65 WATTS

0.20 PER CENT

31 GMS

$7.7 \times 10^{4}$ sOULES

25 MILL : AMPS 


\section{COMPARISON WITH COHMERCIAL BATTERIES}

Batteries powered by radioactivity cannot be compared directly with chemical batteries because the life of the thermal battery is independent of current drain. In particular, a rating in ampere-hours has no meaning so that a comparison of work, in joules, should be made.

The Mallory Mercury Cell (RM4Z) is considered to be an efficient small-size dry cell in terms of energy per: unit mass. It is rated at 2,300 milliampere-hours, which corresponds to a total output of: 8,280 coulombs. The rated voltage is 1.3 volts, and the battery will probably average 1.0 volt over its life-time, so that the total work from an RM4Z cell is 8,280 joules.

The total work which the polonium battery can perform is

$$
J=\frac{1}{100} \int_{0}^{\delta} \text { Eff } \times W_{s} d t
$$

where

$$
W_{s}=W_{s(\max )} e^{-\lambda t}
$$

and $\lambda$ is the radioactive decay constant. In one half-life the efficiency will not decrease appreciably, and one half-life probably represents the useful life of the battery. Then

$$
J=\frac{\operatorname{Eff} W_{S(\max )}}{100} \int_{0}^{T^{\frac{1}{2}}} e^{-\lambda t} d t=\frac{\operatorname{Eff} W_{S(\max )}}{100 \lambda}
$$

The radioactivity constant $\lambda$ is related to the half-life:

$$
\lambda=\frac{0.693}{T \frac{1}{2}}
$$

For polonium, with a half-life of 138,4 days,

$$
\lambda=5.8 \times 10^{-8} \mathrm{sec}^{-1}
$$

From Equation (27) the total useful work of the two completed batteries would be $1.5 \times 10^{4}$ and $7.7 \times 10^{4}$ joules, respectively, or about $1: 8$ and 9.2 times that of the RM4Z ce11. On a weight basis, the polonium batteries weigh 34 and 31 grams, respectively, in comparison to 45 grams for the RM4Z mercury cell.

\section{CONCLUSIONS}

A thermal battery, using polonium-210 as the heat source, has been made which has about 10 times the work capacity of ordinary dry cells of the same weight.

Another advantage of such batteries is the insensitivity of the output to ambient temperatures. From the theory output should increase slowly with decreasing ambient temperatures to absolute zero.

\section{ACKNO WL EDGMENT}

The authors wish to acknowledge the contributions of $J_{0}, L$. Richmond, $R_{0} \cdot J_{0}$ Breen。 E. E. Winterland, and D. U. Wright for the preparation and fabrication of the heat sources used in these batteries. 